\title{
Health hazards from polycyclic aromatic hydrocarbons bound to submicrometer particles in Gliwice (Poland)
}

\author{
Barbara Kozielska ${ }^{1, *}$ \\ ${ }^{1}$ Silesian University of Technology, Faculty of Energy and Environmental Engineering, Department \\ of Air Protection, 22B Konarskiego St., 44-100 Gliwice, Poland
}

\begin{abstract}
Even though there is an eminent reduction of emission of pollution, there is still a serious danger to health caused by atmospheric aerosol. Studies show that particles with aerodynamic diameters not greater than $1 \mu \mathrm{m}$ (PM1) and $2.5 \mu \mathrm{m}$ (PM2.5) are especially dangerous as they have the ability to easily penetrate into the alveoli and then into the circulatory system. What is more, absorbed on their surface for example persistent organic compounds, among them polycyclic aromatic hydrocarbons (PAHs) they have carcinogenic and mutagenic effects. The paper presents concentrations polycyclic aromatic hydrocarbons bound to submicrometer particles (PM1). Samples were collected at the point in southern Poland (Gliwice) with a low volume sampler. Afterwards, they were chemically analysed with a gas chromatograph equipped with a flame ionization detector (Perkin Elmer Clarus 500). The average concentration values of the PAH sum ( $\mathrm{PAH})$ and particular PAHs; the percentages of carcinogenic PAHs in total PAHs $(\Sigma \mathrm{PAH}$ carc $/ \mathrm{PAH})$; toxic equivalent (CEQ); mutagenic equivalent (MEQ); TCDD-toxic equivalent (TEQ). Their high values express the significance of health hazard from PM1 and PM1-bound PAH in Silesia Region.
\end{abstract}

\section{Introduction}

Among the atmospheric pollutants, a particulate matter with an aerodynamic diameter of equal or less than $10 \mu \mathrm{m}$ (PM10) has the most adverse effects on the human health $[1,2]$. Dust particles PM1 (aerodynamic diameter $\leq 1 \mu \mathrm{m}$ ) and PM2.5 (aerodynamic diameter $\leq 2.5 \mu \mathrm{m}$ ) are especially dangerous as they have the ability to easily penetrate into the alveoli and then into the circulatory system [3-5]. According to the World Health Organization [6] prolonged exposure to PM2.5 particulate results in an increase in the incidences of lower respiratory tract diseases, cardiovascular disease, shorter life expectancy, and increases the likelihood of lung cancer [5]. Epidemiological studies have shown that there is an association between total mortality, cardiovascular mortality, respiratory mortality, hospital admissions, and ambient PM10 level [7]. Apart from the described health consequences, the absorption of dust particles by the human organisms

\footnotetext{
* Corresponding author: barbara.kozielska@polsl.pl
} 
constitutes a significant threat with regard to its various chemical compounds that usually have toxic, carcinogenic and mutagenic effects [3, 8-10]. In addition, some components adsorbed on fine dust particles, can cause allergic reactions. Particularly dangerous are toxic metals and their compounds, sulphates, persistent organic compounds with PAHs among them and many others.

PAHs can penetrate into the body via the inhalation route through the respiratory system, via the digestive system - along with food intake, and through the skin [11]. PAHs are inhaled in the form of vapour or together with dust particles they are associated with and/or on which they are adsorbed. Depending on the fraction, dust particles may settle in different sections of the airways. The smallest particles get into the alveoli, where substances adsorbed can go into the bloodstream and spread throughout the body.

PAHs have also the ability to accumulate in adipose tissue due to their lipophilic properties. The measure of the PAHs activity level is the ability of their radical oxidation. As a result of metabolic changes in the body, PAHs form oxides of arenes, phenols, diols, and quinones $[3,8,12-15]$. When PAHs are metabolized by specific enzyme systems to epoxides, metabolites have the ability to attach to DNA, RNA, and proteins $[15,16]$. Such combinations are the cause of cancer formation, inhibition and errors in protein replication, transcription and biosynthesis $[3,13,17,18]$.

Until now, however, it has not been clearly established whether individual PAHs or their sum are responsible for the formation of neoplastic changes [19-21]. It is particularly difficult to assess the impact of PAHs adsorbed on particulate matter in the air, because individual hydrocarbons can react with other components emitted from incomplete combustion processes, causing an increase or weakening of their carcinogenic properties.

The US EPA recognizes sixteen PM-bound PAH as priority pollutants (naphthalene, acenaphthylene, acenaphthene, fluorene, phenantrene, anthracene, fluoranthene, pyrene, benzo[a]anthracene, chrysene, benzo[b]fluoranthene, benzo[k]fluoranthene, benzo[a]pyrene, indeno[1,2,3-cd]pyrene, dibenzo[ah]anthracene and benzo[ghi]perylene).

The goal of the present study was to investigate the concentrations of PM1-bound phase of these 16 PAH in Gliwice - a city of a medium size in southern Poland. The level of the health hazard to humans from the mixture of PAH (i.e., equivalents: toxic - TEQ, mutagenic - MEQ, and cancerogenic (TCDD-2,3,7,8-Tetrachlorodibenzo-p-dioxin - CEQ) and $\sum \mathrm{PAH}_{\text {carc }} / \sum \mathrm{PAH}$ were also determined.

\section{Materials and methods}

The 24-hr samples of PM1 were collected in April-June in Gliwice (Fig.1). The air temperature in the measuring period was between $7-20^{\circ} \mathrm{C}$ (av. $\left.15^{\circ} \mathrm{C}\right)$. At a measuring site PM1 was sampled using Atmoservice MVS. It was sampled at an air flow rate of $2.3 \mathrm{~m}^{3} / \mathrm{hr}$ onto quartz fibre filters which earlier were conditioned in a weighing room. The weight of PM1 collected was determined gravimetrically (Radwag microbalance, resolution $1 \mu \mathrm{g}$ ).

The PM1 was extracted from filters with dichloromethane (DCM) in an ultrasonic bath. For selective purification, the solid phase of samples was extracted (SPE) in the C-18 packed columns. Finally, the PAH extracts were thickened to $0.1 \mathrm{~cm}^{3}$. The SPE extracts were analysed with the Clarus 500 Perkin Elmer gas chromatograph, equipped with a Restek RTX-5 capillary column and flame ionization detector (FID).

The extraction, the chromatography technique, and validation parameters are described in detail in $[22,23]$. 


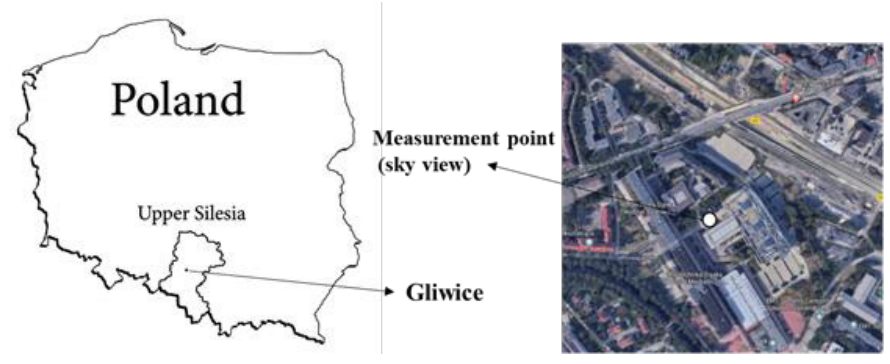

Fig. 1. Location of the measurement point in Gliwice (Map data: 2018@ Google, ORION-ME).

The cumulative health hazard from a mixture of PAH can be assessed by using the TEQ, MEQ, or CEQ equivalents relative to the toxicity or mutagenicity of $\mathrm{BaP}$, or to the carcinogenicity of 2,3,7,8-tetrachlorodibenzo-p-dioxin, respectively. TEQ, MEQ, and CEQ were computed as linear combinations of the PAH concentrations and respective equivalence factors: TEF, MMC, TCDD-TEF (Table 1). Additionally, the proportion of the sum of the carcinogenic $\mathrm{PAH}\left(\sum \mathrm{PAH}_{\mathrm{carc}}\right)$ concentrations to the sum of the concentrations of the 16 determined PAH ( $\left.\sum \mathrm{PAH}\right)$ was computed.

Table 1. The value of toxicity equivalence factors TEF [24], mutagenic equivalence factors MMC [25], carcinogenic equivalence factors TCDD-TEF [26] for PAH and the carcinogenic PAH (+) [27].

\begin{tabular}{|l|l|c|c|c|c|}
\hline \multicolumn{1}{|c|}{ Compound name } & Abbrev. & TEF & MMC & TCDD-TEF & Carc \\
\hline Naphthalene & $\mathrm{Na}$ & 0.001 & & & \\
\hline Acenaphthylene & $\mathrm{Acy}$ & 0.001 & 0.00056 & & \\
\hline Acenaphthene & $\mathrm{Ace}$ & 0.001 & & & \\
\hline Fluorene & $\mathrm{Flu}$ & 0.001 & & & \\
\hline Phenantrene & $\mathrm{Ph}$ & 0.001 & & & \\
\hline Anthracene & $\mathrm{An}$ & 0.01 & & & \\
\hline Fluoranthene & $\mathrm{Fl}$ & 0.001 & & & \\
\hline Pyrene & $\mathrm{Py}$ & 0.001 & & & \\
\hline Benzo[a]anthracene & $\mathrm{BaA}$ & 0.1 & 0.082 & 0.000025 & + \\
\hline Chrysene & $\mathrm{Ch}$ & 0.01 & 0.017 & 0.00020 & + \\
\hline Benzo[b]fluoranthene & $\mathrm{BbF}$ & 0.1 & 0.25 & 0.00253 & + \\
\hline Benzo[k]fluoranthene & $\mathrm{BkF}$ & 0.1 & 0.11 & 0.00487 & + \\
\hline Benzo[a]pyrene & $\mathrm{BaP}$ & 1 & 1 & 0.000354 & + \\
\hline Indeno[1,2,3-cd]pyrene & $\mathrm{IP}$ & 0.1 & 0.31 & 0.00110 & + \\
\hline Dibenzo[ah]anthracene & $\mathrm{DBA}$ & 5 & 0.29 & 0.00203 & + \\
\hline Benzo[ghi]perylene & $\mathrm{BghiP}$ & 0.01 & 0.19 & & \\
\hline
\end{tabular}

\section{Results and discussion}

The average concentration of PM1 during spring in Gliwice was $23.9 \mu \mathrm{g} / \mathrm{m}^{3}$ (range $9.9-$ $73.7 \mu \mathrm{g} / \mathrm{m}^{3}$ ) (Table 2). This is the value higher than the ones noted during a non-heating season in Katowice, where the mean PM1 concentrations were $18.4 \mu \mathrm{g} / \mathrm{m}^{3}$ and $20.8 \mu \mathrm{g} / \mathrm{m}^{3}$ at traffic point and urban background measurement point respectively and in Złoty Potok regional background measurement point where value $10.3 \mu \mathrm{g} / \mathrm{m}^{3}$ was observed [23]. Also in Warsaw summer concentration of PM1 were a lot lower and comprised between $5.7 \mu \mathrm{g} / \mathrm{m}^{3}$ to $22.6 \mu \mathrm{g} / \mathrm{m}^{3}$ (average $11.1 \mu \mathrm{g} / \mathrm{m}^{3}$ ) [28]. When compared to the other places in the world, these concentrations were substantially high. For example, summer concentrations of PM1 observed in Šlapanice and Brno (Czech Republic) in 2010 were 
$11.6 \mu \mathrm{g} / \mathrm{m}^{3}$ and $12.9 \mu \mathrm{g} / \mathrm{m}^{3}$, respectively [29], in Venice-Mestre (Italy) in the year $2014-$ $6.4 \mu \mathrm{g} / \mathrm{m}^{3}$ [30]. In Canoas (Brasil) Agudelo-Castañeda and Teixeira measured even lower PM1 concentrations $\left(8.6 \mu \mathrm{g} / \mathrm{m}^{3}\right)$ [31].

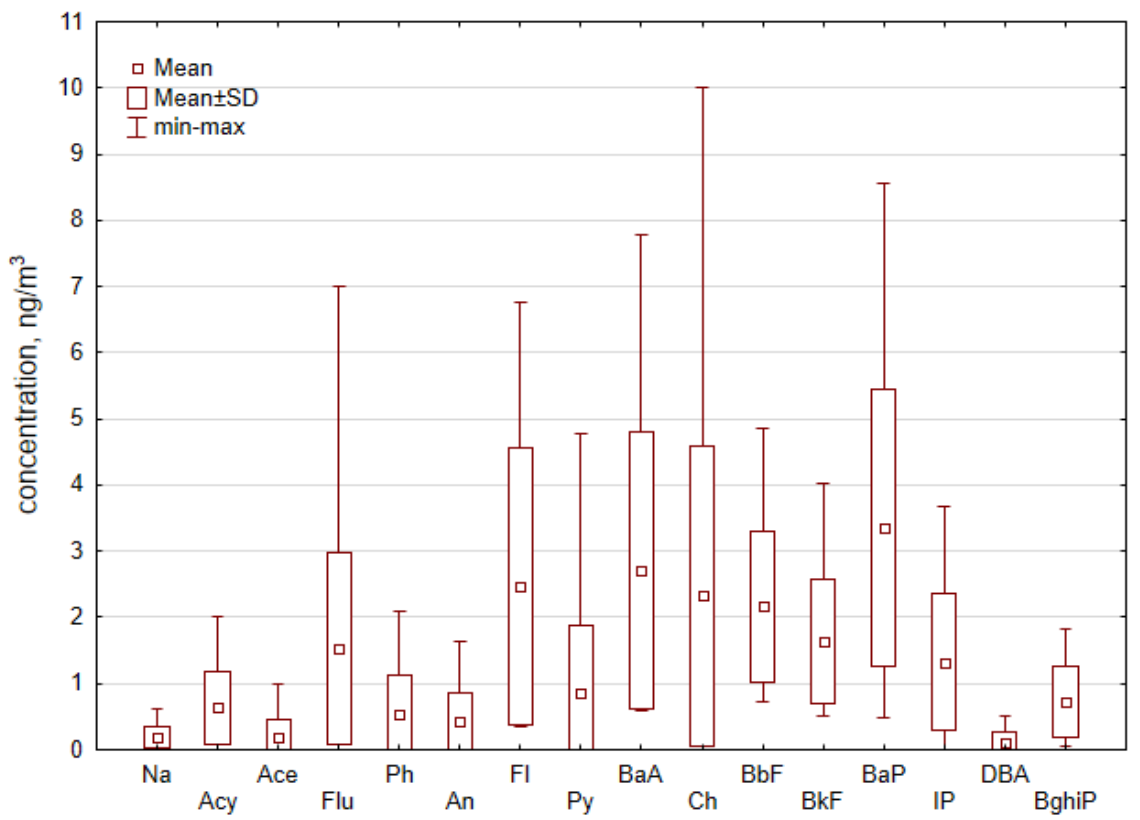

Fig. 2. The mean, mean \pm standard deviation, minimal, maximal concentrations of particular PM1bound PAHs in the air in Gliwice during whole measurement period $\left(\mathrm{ng} / \mathrm{m}^{3}\right)$.

In Gliwice average concentration of the $16 \mathrm{PAH}$ sum $(\Sigma \mathrm{PAH})$ was $21.2 \mathrm{ng} / \mathrm{m}^{3}$ with the maximum amounting $52.4 \mathrm{ng} / \mathrm{m}^{3}$ (Table 2). This average is comparable to the one noted in Złoty Potok in a non-heating $-18.6 \mathrm{ng} / \mathrm{m}^{3}$, and aprox. 2.6 times lower than in Katowice at traffic point $-56.0 \mathrm{ng} / \mathrm{m}^{3}$ [23]. One should mention that in summer average concentrations of $\mathrm{SPAH}$ in the other sites in Poland or Europe are lower. For example average concentrations of PM1-bound PAHs in Zabrze was $3.5 \mathrm{ng} / \mathrm{m}^{3}$ [37], in Brno and Šlapanice (Czech Republic) were $1.7 \mathrm{ng} / \mathrm{m}^{3}$ and $1.5 \mathrm{ng} / \mathrm{m}^{3}$, respectively [29], and in Virolahti (Finland) $1.8 \mathrm{ng} / \mathrm{m}^{3}$ [32] alike. A bit lower $\Sigma \mathrm{PAH}$ concentrations in the summer then in winter can be caused by high ambient insolation, air temperatures and ozone concentrations favorable to the intense PAH conversion, and to the evaporation of light PAH from PM and their staying in gaseous form in the air [33]. The mean concentrations of $16 \mathrm{PAHs}$ were in the decreasing order $\mathrm{BaP}>\mathrm{BaA}>\mathrm{Fl}>\mathrm{BbF}>\mathrm{BkF}>\mathrm{Flu}>\mathrm{IP}>\mathrm{Py}>\mathrm{BghiP}>\mathrm{Acy}>\mathrm{Ph}>$ $\mathrm{An}>$ Ace $>\mathrm{Na}>\mathrm{DBA}\left(0.11-3.35 \mathrm{ng} / \mathrm{m}^{3}\right)$ (Fig 2). In Gliwice BaP, BaA, Fl, BbF and BkF constituted $61.6 \%$ of the $\sum \mathrm{PAH}$ mass.

Among investigated compounds, $\mathrm{BaP}$ is the one of a great interest considering its well known carcinogenic and mutagenic properties. The concentration of PM1-bound BaP was in the range of 0.49 to $8.57 \mathrm{ng} / \mathrm{m}^{3}$ (average $3.35 \mathrm{ng} / \mathrm{m}^{3}$ ) which was the highest values among the whole PAHs under interest (Table 2). For the examined point $\mathrm{BaP}$ was $4.7 \%$ $20.5 \%$ (average $15.9 \%$ ) in $\Sigma \mathrm{PAH}$ over the whole measurement period. The ambient concentration of the PM10-bound BaP has the formal limit that should not be exceeded; the yearly permissible ambient concentration of PM10-bound $\mathrm{BaP}$ is $1 \mathrm{ng} / \mathrm{m}^{3}$ [34]. The high $\mathrm{BaP}$ concentrations are observed in Poland not only in the heating season but also in the remaining part of the year $[22,23,35]$. Such a situation was not the case in other European regions where concentrations in summer are substantially lower e.g in Czech Republic, 
Spain, Portugal (Table 3). On the other hand the summer concentrations of PM1-bound BaP in Chennai City (India) was similar to the Polish ones or even higher $\left(6.2 \mathrm{ng} / \mathrm{m}^{3}-25.6\right.$ $\left.\mathrm{ng} / \mathrm{m}^{3}\right)[36]$.

Table 2. Mean concentrations along with \pm standard deviation (SD), min, max of PM1, $\sum \mathrm{PAH}, \mathrm{BaP}$ and TEQ, MEQ, CEQ, $\mathrm{PAH}_{\text {cand }} / \sum \mathrm{PAH}$ in the air in Gliwice.

\begin{tabular}{|l|c|c|c|}
\hline & Mean \pm SD & Min & Max \\
\hline $\mathbf{P M 1}, \square \mathbf{g} / \mathbf{m}^{\mathbf{3}}$ & $23.921 \pm 14.94$ & 9.873 & 73.723 \\
\hline$\sum \mathbf{P A H}, \mathbf{n g} / \mathbf{m}^{\mathbf{3}}$ & $21.158 \pm 11.58$ & 8.870 & 52.446 \\
\hline $\mathbf{B a P}, \mathbf{n g} / \mathbf{m}^{\mathbf{3}}$ & $3.349 \pm 2.08$ & 0.487 & 8.566 \\
\hline $\mathbf{T E Q}, \mathbf{n g} / \mathbf{m}^{\mathbf{3}}$ & $4.753 \pm 3.24$ & 1.021 & 13.156 \\
\hline $\mathbf{M E Q}, \mathbf{n g} / \mathbf{m}^{\mathbf{3}}$ & $4.912 \pm 2.94$ & 1.308 & 12.129 \\
\hline $\mathbf{C E Q}, \mathbf{p g} / \mathbf{m}^{\mathbf{3}}$ & $16.863 \pm 9.55$ & 5.751 & 40.641 \\
\hline $\mathbf{P A H}_{\text {canc }} / \mathbf{P A H}$ & $0.630 \pm 0.08$ & 0.507 & 0.795 \\
\hline
\end{tabular}

Table 3 presents $\mathrm{BaP}$ concentrations and the following indicators of the exposure to the PAH mixture: toxic equivalent (TEQ), mutagenic equivalent (MEQ), carcinogenic equivalent (CEQ), and share of seven PAHs, with carcinogenic influence revealed in a table lin the $\mathrm{PPAH}$. Additionally, the measurements results from other locations, taken from the publications quoted in Table 3, are shown.

Table 3. The concentration of BaP, equivalents TEQ, MEQ, CEQ and the share of carcinogenic PAH in $\Sigma \mathrm{PAH}$ for PM1-bound PAH in Poland and other locations in non-heating season or summer.

\begin{tabular}{|c|c|c|c|c|c|}
\hline \multirow{2}{*}{ Location } & BaP & TEQ & MEQ & \multirow{2}{*}{$\begin{array}{l}\text { CEQ } \\
\mathrm{pg} / \mathrm{m}^{3}\end{array}$} & \multirow{2}{*}{$\mathbf{P A H}_{\text {canc }} / \sum \mathbf{P A H}$} \\
\hline & \multicolumn{3}{|c|}{$\mathrm{ng} / \mathrm{m}^{3}$} & & \\
\hline Gliwice - this study & 3.35 & 4.75 & 4.91 & 16.86 & 0.63 \\
\hline Katowice, UB [23] & 2.97 & 5.29 & 4.23 & 13.71 & 0.59 \\
\hline Katowice, traffic point [23] & 4.73 & 15.46 & 6.45 & 20.42 & 0.55 \\
\hline Zloty Potok, RB, [23] & 2.46 & 4.50 & 4.29 & 13.80 & 0.50 \\
\hline Zabrze, UB [37] & 0.17 & 0.62 & 0.38 & 3.33 & 0.43 \\
\hline Katowice, city center [35] & 1.48 & 2.06 & 1.69 & 96.1 & 0.62 \\
\hline $\begin{array}{l}\text { Brno, Czech Republic, large city [29Bląd! } \\
\text { Nie zdefiniowano zakladki.] }\end{array}$ & 0.15 & 0.45 & 0.29 & 0.83 & 0.54 \\
\hline Šlapanice, Czech Republic, small town [28] & 0.15 & 0.35 & 0.27 & 0.79 & 0.59 \\
\hline Madrid, Spain, UB [38] & 0.02 & 0.10 & 0.05 & 0.26 & 0.57 \\
\hline & 0.05 & 2.45 & 0.29 & 1.69 & 0.70 \\
\hline North or & 0.12 & 2.69 & 0.42 & 2.20 & 0.52 \\
\hline
\end{tabular}

UB - urban background, RB - regional background

In these studies, the mean TEQ, MEQ and CEQ were $4.75 \mathrm{ng} / \mathrm{m}^{3}$ (range: 1.02 $13.16 \mathrm{ng} / \mathrm{m}^{3}$ ), $4.91 \mathrm{ng} / \mathrm{m}^{3}$ (range: $1.31-12.13 \mathrm{ng} / \mathrm{m}^{3}$ ) and $16.89 \mathrm{pg} / \mathrm{m}^{3}$ (range: $5.75-40.64$ $\mathrm{pg} / \mathrm{m}^{3}$ ), respectively (Table 2). They were unquestionably high and comparable to the ones obtain in [23] except the traffic point in Katowice, where TEQ were three times higher than observed during this investigations. In the European cities, the TEQ, MEQ, CEQ values were lower than in Gliwice (Table 3).

The values of TEQ, MEQ, CEQ obtained for Asian cities (e.g., Chennai City and Delhi in India) were as high as or higher than those observed in Poland. For example, the values of TEQ, MEQ, CEQ observed for Chennai City in the urban area in summer were $44.3 \mathrm{ng} / \mathrm{m}^{3}, 77.4 \mathrm{ng} / \mathrm{m}^{3}$ and $246.7 \mathrm{pg} / \mathrm{m}^{3}$, respectively [23, 36]. 
Also the more general tendency can be pointed - regardless of the season these values are generally higher in Poland than, in the European cities and similar or lower Asian cities.

The sum of seven carcinogenic PAHs concentrations were in the range of $5.04 \mathrm{ng} / \mathrm{m}^{3}$ to $33.18 \mathrm{ng} / \mathrm{m}^{3}$. The average value of $\sum \mathrm{PAH}_{\text {carc }} / \sum \mathrm{PAH}$ was 0.63 . In other regions of Silesia this value is usually lower (Table 3 ).

\section{Summary and conclusions}

The PM1 samples were collected from April to June. This period excluded the heating season, when in Gliwice occurs intensive emissions of PM and PAH from domestic coalfired stoves and heating plants, coal-fired as well. It also didn't include summer season which is characterized by a strong insolation, high ambient temperatures and ozone concentrations and the presence in the atmosphere other compounds favorable to the PAH transformations. In these conditions, PAHs three and less aromatic rings have the tendency to evaporate from PM surface into the air in the gaseous form. Despite this common tendency, average concentrations of PM1 and $\sum \mathrm{PAH}$ were unexpectedly high reaching in the air in Gliwice area values $23.92 \mu \mathrm{g} / \mathrm{m}^{3}$ and $21.16 \mathrm{ng} / \mathrm{m}^{3}$, respectively. In the same time mass percentage of four- and five-ring PAHs in $\Sigma \mathrm{PAH}$ was up to $77 \%$.

High percentage of $\mathrm{BaP}$ in the $\Sigma \mathrm{PAH}(4.7 \%-20.5 \%)$ and high ambient concentrations of the PM1-bound $\mathrm{BaP}$ may pose a serious threat to the inhabitants of the City. Also values of subsequent equivalents TEQ $\left(4.47 \mathrm{ng} / \mathrm{m}^{3}\right)$, MEQ $\left(4.91 \mathrm{ng} / \mathrm{m}^{3}\right)$, CEQ $\left(16.86 \mathrm{pg} / \mathrm{m}^{3}\right)$ indicate the serious health hazard for humans. They are higher than observed in other places in Poland and Europe, and similar or lower than noted in Asian cities during comparable measurement periods.

The concentrations proportion of the $\sum \mathrm{PAH}_{\text {carc }}$ to $\sum \mathrm{PAH}$ was 0.63 . This value belongs to the highest noted in the world in a summer period (the closer this value is to 1 , the more hazardous $\sum$ PAH to human's health).

Generally, the health hazard from the 16 US EPA PM1-bound PAHs in Gliwice is greater than in majority of cities where such hazard was evaluated. On the base of other avaliable investigations $[22,23]$ one can assume with a high possibility that this threat will be much higher during the heating seasons.

This work was supported by the Faculty of Power and Environmental Engineering, Silesian University of Technology (statutory research).

\section{References}

1. H. Biglari, S. Geravandi, M.J. Mohammadi, E.J. Porazmey, R.Z. Chuturkova, Y.O. Khaniabadi, G. Goudarzi, M. Mahboubi, B. Mohammadi, A.R. Yari, Fresenius Environ. Bull. 26, 4047 (2017)

2. G. Goudarzi, S. Daryanoosh, H. Godini, P.K. Hopke, P. Sicard, A. De Marco, H.D. Rad, A. Harbizadeh, F. Jahedi, M.J. Mohammadi, J. Savari, S. Sadeghi, Z. Kaabi, Y. Omidi Khaniabadi, Public Health 148, 109 (2017)

3. T.M. De Kok, J.G. Hogervorst, J.J. Briedé, M.H. Van Herwijnen, L.M. Maas, E.J. Moonen, H.A. Driece, J.C. Kleinjans, Environ. Mol. Mutagen. 46, 71 (2005)

4. U. Kraus, S. Breitner, J. Schnelle-Kreis, J. Cyrys, T. Lanki, R. Rückerl, A. Schneider, I. Brüske, J. Gu, R. Devlin, H.-E. Wichmann, R. Zimmermann, A. Peters, Inhal. Toxicol. 23, 431 (2011)

5. T.W. Hesterberg, C.M. Long, W.B. Bunn, C.A. Lapin, R.O. McClellan, P.A. Valberg, Inhal. Toxicol. 24, 1 (2012) 
6. WHO Air Quality Guidelines. Global Update 2005. Particulate Matter, Ozone, Nitrogen Dioxide and Sulfur Dioxide (2006) WHO; Regional Office for Europe (Accessed in May 2016)

http://www.euro.who.int/_data/assets/pdf_file/0005/78638/E90038.pdf

7. S. Jeong, The impact of air pollution on human health in Suwon City. Asian J. Atmos. Environ. 7, 227 (2013)

8. T.J. Siaga, W.J. Bracken, G. Gleason, W. Levin, A.H. Conney, H. Yagi, D.M. Jerina, Cancer Res. 39, 67 (1979)

9. J. Yan, L. Wang, P.P. Fu, H. Yu, Mutat. Res. Genet. Toxicol. Environ. Mutagen. 557, $99(2004)$

10. K.H. Kim, S.A. Jahan, E. Kabir, R.J.C. Brown, Environ. Int. 60, 71 (2013)

11. H.C. Wang, D.H. Jiang, Q. Wang, Adv. Mater. Res. 201-203, 2634 (2011)

12. J. Jacob, G. Grimmer, G. Dettbarn, Biomark. 4, 319 (1999)

13. T. Shi, A.M. Knaapen, J. Begerow, W. Birmili, P.J. Borm, R.P. Schins, Occup. Environ. Med. 60, 315 (2003)

14. G. St. Helen, M.L. Goniewicz, D. Dempsey, M. Wilson, III P. Jacob, N.L. Benowitz, Chem. Res. Toxicol. 25, 952 (2012)

15. E.W.Y. Tung, N.A. Philbrook, C.L. Belanger, S. Ansari, L.M. Winn, Mutat. Res. Genet. Toxicol. Environ. Mutagen. 760, 64 (2014)

16. I.W.H. Jarvis, K. Dreij, A. Mattsson, B. Jernström, U. Stenius, Toxicol. 321, 27-39 (2014)

17. P.H. Danielsen, P. Møller, K.A. Jensen, A.K. Sharma, H. Wallin, R. Bossi, H. Autrup, L., Mølhave, J.-L. Ravanat, J.J. Briedé, T.M. De Kok, S. Loft, Chem. Res. Toxicol. 24, 168 (2011)

18. Borm P.J.A., Cakmak G., Jermann E., Weishaupt, C., Kempers, P., Van Schooten, F.J., Oberdörster G., Schins R.P.F., Toxicol. Appl. Pharmacol. 205, 157 (2005)

19. P.A. White, Mutat. Res. 515, 85 (2002)

20. P. Rossner, J. Topinka, J. Hovorka, A. Milcova, J. Schmuczerova, J. Krouzek, R.J. Sram, Toxicol. Lett. 198, 312 (2010)

21. P. Rossner, J. Topinka, J. Hovorka, A. Milcova, J. Schmuczerova, J. Krouzek, R.J. Sram, Toxicol. Lett. 98, 304 (2010)

22. W. Rogula-Kozłowska, B. Kozielska, K. Klejnowski, Bull. Environ. Contam. Toxicol. 91, 349 (2013)

23. B. Kozielska, W. Rogula-Kozłowska, K. Klejnowski, Atmosphere 6, 1 (2015)

24. I.C.T. Nisbet, P.K. LaGoy, Regul. Toxicol. Pharmacol. 16, 290 (1992)

25. J.L. Durant, W.F. Busby Jr., A.L. Lafleur, B.W. Penman, C.L. Crespi,. Mutat. Res. Genet. Toxicol. 371, 123 (1996)

26. K.L. Willett, P.R. Gardinali, J.L. Sericano, T.L. Wade, S.H. Safe, Arch. Environ. Contam. Toxicol. 32, 442 (1997)

27. US EPA, 2008. Polycyclic Aromatic Hydrocarbons (PAHs) - EPA Fact Sheet. National Center for Environmental Assessment, Office of Research and Development, Washington, DC, USA.

28. G. Majewski, W. Rogula-Kozłowska, K. Rozbicka, P. Rogula-Kopiec, B. Mathews, A. Brandyk, Aerosol Air Qual. Res. 18, 636 (2018)

29. K. Křůmal, P. Mikuška, Z. Večeřa, Atmos. Environ. 67, 27 (2013) 
30. S. Squizzato, M. Masiol, C. Agostini, F. Visin, G. Formenton, R.M. Harrison G. Rampazzo, Atmos. Res. 180, 262 (2016)

31. D.M. Agudelo-Castañeda, E.C. Teixeira, Atmos. Environ. 96, 186 (2014)

32. U. Makkonen, H. Hellén, P. Anttila, M. Ferm, Sci. Total Environ. 408, 644 (2010)

33. Dvorská, G. Lammel, J. Klánová, Atmos. Environ. 45, 420 (2011)

34. EC. Council Directive 2004/107/EC Relating to Arsenic, Cadmium, Mercury, Nickel and Polycyclic Aromatic Hydrocarbons in Ambient Air

35. B. Kozielska, W. Rogula-Kozłowska, P. Rogula-Kopiec, I. Jureczko, Ecol. Eng. 49, 25 (2016)

36. R. Mohanraj, G. Solaraj, S. Dhanakumar, Environ. Sci. Pollut. Res. 18, 764 (2011)

37. W. Rogula-Kozłowska, B. Kozielska, B. Błaszczak, K. Klejnowski, The mass distribution of particle-bound PAH among aerosol fractions: A case-study of an urban area in Poland. In Organic Pollutants Ten Years after the Stockholm ConventionEnvironmental and Analytical Update; Puzyn, T., Mostrag-Szlichtyng, A., Eds.; InTech: Rijeka, Croatia,163-190 (2012)

38. F. Mirante, C. Alves, C. Pio, O. Pindado, R. Perez, M.A. Revuelta, B. Artiñano, Atmos. Res. 132-133, 345 (2013)

39. M. Oliveira, K. Slezakova, J. Madureira, E. de Oliveira Fernandes, C. Delerue-Matos, S. Morais, M. do Carmo Pereira, Sci. Total Environ. 575, 1156 (2016) 